\title{
Effect of foliar sprays on fruit retention, quality and yield of Costata persimmon trees
}

\author{
H. A. Kassem ${ }^{1 *}$, Amal M. El-Kobbia ${ }^{2}$, Hend A. Marzouk ${ }^{2}$ and \\ Mohamed M. El- Sebaiey ${ }^{2}$
}

\begin{abstract}
${ }^{1}$ Plant Production Department, Faculty of Food and Agricultural Sciences, King Saud University, Saudi Arabia; ${ }^{2}$ Pomology Department, Faculty of Agriculture (El-Shatby), Alexandria University, Alexandria, Egypt
\end{abstract}

\begin{abstract}
The present investigation was carried out during the two successive years of 2006 and 2007 on "Costata" persimmon trees in order to study the influence of foliar sprays of different chemicals on the fruit retention, fruit quality and yield.Trees were sprayed at pea stage $(5 \mathrm{~mm}$ fruitlet diameter), marble stage ( $15 \mathrm{~mm}$ fruitlet diameter) or at both stages with urea, phosphoric acid, potassium nitrate, Ca-EDTA, Fe-EDTA + Zn- EDTA + Boric acid, NAA, GA 4 , Amcotone, activated dry yeast and a mixture of ascorbic plus citric acids. All sprayed chemicals significantly increased vegetative growth, fruit retention, tree yield in both seasons . $\mathrm{GA}_{4}$ had the highest fruit retention and yield followed by Amcotone and activated dry yeast and then NAA as compared with all other treatments in both seasons. All sprayed compounds increased fruit weight ,TSS, total sugars, reducing sugars, carotene and V.C contents and decreased fruit acidity and tannin contents as compared with all other treatments in both seasons. $\mathrm{GA}_{4}$ had the highest fruit weight, followed by activated dry yeast and mixture of ascorbic acid + citric acid and then Amcotone. Phosphoric acid recorded the highest values of fruit TSS, total sugars, reducing sugars and carotene contents, whereas activated dry yeast gave the highest V.C and lower tannine contents as compared with all other chemicals in both seasons. Foliar sprays at pea + marble stages recorded the highest values of all the investigated parameters in both seasons as compared with pea or marble stage.
\end{abstract}

Keywords: activated dry yeast, foliar sprays, fruit retention, $\mathrm{GA}_{4}$, NAA, persimmon, quality, yield.

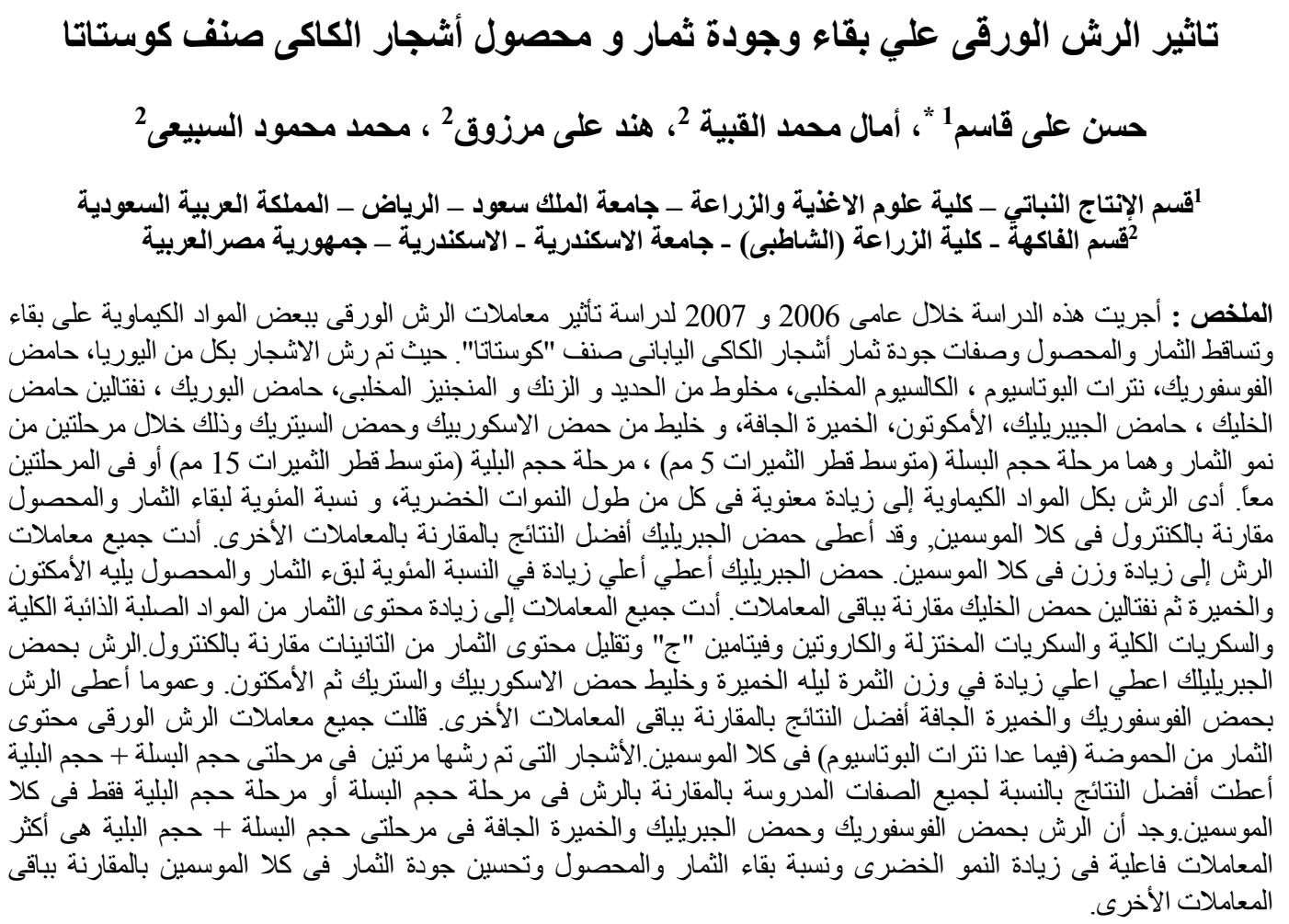

* Corresponding Athor, Email: kassem60@yahoo.com 


\section{Introduction}

Costata cultivar is the leading and the main persimmon variety progressively consumed in the Egyptian market and exportation. However, the problem of June drop and pre-harvest fruit drop exists extensively in many Egyptian orchards, especially because that Costata persimmon is a parthenocarpic cultivar thus eliminating yield and fruit quality. Young parthenocarpic fruits tend to be more easily to drop than young fruits from pollinated flowers (Schafer et al., 1999). The high drop of fruits before maturity is a major problem in Egypt that affects persimmon final yield and production (El-Shaikh et al., 1999), especially Costata cultivar which drop its fruits profusely (Kabeel, 1999; Wally, 2003). Different factors might cause persimmon fruit drop. Abd El-Ghany (2005) reported that, fruit drop before June drop (initial drop) occurred due to the competition among the fruit on the nutrients, water and the defect in hormonal balance. Elizabeth (1991) stated that, there were two maximum dates for persimmon fruit drop; 55 and 77 days after flowering, which occurred when the fruit reaches a diameter of 2.6 and $4.5 \mathrm{~cm}$ respectively,which coinciding with the rapid fruit growth period. In addition, Costata yield shows a wide variation in fruit quality characteristics such as size, shape and color, thus, influencing its marketing. Several approaches had been made in order to increase persimmon fruit quality by spraying the trees with plant nutrients (Kabeel, 1999; Wally et al., 1999; Eliwa et al., 2003). Nitrogen, phosphorous, potassium and calcium are important nutrients needed for fruit growth and quality (Rizzi and Abruzzese, 1990). Moreover, many micro-nutrients such as iron, zinc and boron are needed for different biological functions that might be attributed to tree yield and fruit quality (Shoeib and El-Sayed, 2003). The plant growth regulators (PGR) act as messenger and are needed in small quantities at low concentrations. Generally their site of action and biosynthesis are different. Most of the plant growth regulators exhibit a broad spectrum and thus a single PGR may influence several entirely different processes. Such as NAA and $\mathrm{GA}_{3}$ affects fruit formation, abscission cell elongation, apical dominance, photoperiod and geotropism. Growth regulating substances such as NAA, 2, 4-D, 2, 4-5-TP and IBA have been used by some workers to control pre-harvest fruit drop in mango, citrus and apple and have reported very encouraging results (Haidry et al., 1997; Aboutalebi and Beharoznam, 2006). El-Shewy (1999) observed that $50 \mathrm{mg}$ NAA and $50 \mathrm{mg} \mathrm{GA}_{3}$ per litre at full bloom and three months after $1^{\text {st }}$ spray were most effective treatments in reducing pre harvest fruit drop as well as fruit seed contents in guava. Iqbal et al. (2009) reported that NAA significantly reduced preharvest fruit drop and increased yield and fruit quality. Similar results were also reported by Maurya and Singh (1981) applied GA and NAA before flowering, followed by three weeks after fruit setting and observed that foliar application of NAA significantly increased fruit length, diameter and fruit weight and ultimately crop yield. Dutta and Banik (2007) applied foliar feeding of nutrients and plant growth regulators (GA and NAA) before flowering, followed by three weeks after fruit setting and observed that foliar feeding of nutrients and plant growth regulators significantly increased the fruit length, diameter, individual fruit weight and ultimately crop yield.

Also, using activated dry yeast, as newly natural and safe biostimulant is widely tried (Mansour, 1998; Attala et al., 2000). However, the various positive effects of applying active dry yeast were attributed to its own from different nutrients, high percentage of proteins, large amount of vitamin B and the natural plant growth hormone namely cytokinins (Abd- Elmotty and Fawzy, 2005). Similarly, ascorbic and citric acids as natural and organic antioxidants 
compounds have an auxinc action and synergistic effect on improving fruit retention (Nomier, 2000; Ahmed et al., 2002).

The present study was undertaken to see the effect of of urea, phosphoric acid, potassium nitrate, chelated calcium, a mixture of chealted iron, chelated zinc and boric acid, NAA, GA4, Amcotone, activated dry yeast and a mixture of ascorbic and citric acids sprays at different fruit developmental stages; pea stage, marble stage, or at both stages on improving Costata persimmon fruit retention, yield and fruit quality.

\section{Material and methods}

\section{Plant material and treatments}

The present study was carried out during 2006 and 2007 growing seasons on 5 years old "Costata" persimmon trees (Diospyros kaki L.) budded on Tarabouls root stock. Trees were grown in a clay soil with water table depth of $120 \mathrm{~cm}$ and $\mathrm{pH}$ of 7.8-7.9 in a private orchard situated at El-Tarh region, El-Behera governorate. Trees were planted at $3.5 \mathrm{~m}$ apart and subjected to the same cultural practices usually done in the orchard. Trees were irrigated every two weeks and fertilized with organic manure at a rate of $25 \mathrm{~m}^{3}$ per feddan in November in both years.

Calcium super phosphate $(15 \%$ $\mathrm{P}_{2} \mathrm{O}_{2}$ ) was added during February at a rate of $150 \mathrm{~kg}$ per feddan in the two successive yerars. Also, $200 \mathrm{~kg}$ per feddan ammonium nitrate $(33.5 \% \mathrm{~N})$ and $150 \mathrm{~kg}$ per feddan potassium sulphate $\left(48 \% \quad \mathrm{~K}_{2} \mathrm{O}\right)$ were added. Both fertilizers amounts were divided into three doses; at the beginning of March, May and late June.

The experiment was designed as a split-plot design in a randomized complete block design. The chemical substances comprised the main factor and the fruit physiological stages as sub- main factor. Trees were selected as uniform as possible and the following foliar spray treatments were obtained (main factor):

$\mathrm{T} 1=$ Control (water only).

$\mathrm{T} 2=$ Urea at $2.5 \mathrm{~g} / \mathrm{L}$.

$\mathrm{T} 3=$ Phosphoric acid at $3 \mathrm{~g} / \mathrm{L}$.

$\mathrm{T} 4=$ Potassium nitrate at $3 \mathrm{~g} / \mathrm{L}$.

T5 $=$ Chelated calcium (Ca - EDTA $14 \%)$ at $5 \mathrm{~g} / \mathrm{L}$.

T6= A mixture of (Fe - EDTA $12 \%)$ at 0.3 $\mathrm{g} / \mathrm{L}+(\mathrm{Zn}-$ EDTA $14 \%)$ at $0.3 \mathrm{~g} / \mathrm{L}+$ boric acid at $0.2 \mathrm{~g} / \mathrm{L}$.

$\mathrm{T} 7=$ Naphthalene acetic acid at $25 \mathrm{ppm}$.

$\mathrm{T} 8=$ Gibberellic acid $\left(\mathrm{GA}_{4}\right)$ at $25 \mathrm{ppm}$.

$\mathrm{T} 9=$ Amcotone (contains $0.45 \%$ NAA + $1.25 \%$ NAAM) at 600 ppm (2.7 ppm NAA +7.5 ppm NAAM).

$\mathrm{T} 10=$ Activated dry yeast at $4.20 \mathrm{~g} / \mathrm{L}$.

$\mathrm{T} 11=\mathrm{A}$ mixture of ascorbic acid at $0.8 \mathrm{~g} / 1$ + citric acid at $0.8 \mathrm{~g} / \mathrm{L}$.

All the chemicals were sprayed once at pea stage $(5 \mathrm{~mm}$ fruitlet diameter), marble stage (15 mm fruitlet diameter) and at both stages (sub- main factor). Three replicates were used for each treatment and every replicate was represented by single tree $(11$ chemical treatment $\times 3$ stages $\times 3$ replicates $=99$ experimental unit). Each tree was sprayed with 4 liters of the spraying solution until run-off and New Bio-film was used as a surfactant agent at $0.3 \mathrm{ml} / \mathrm{L}$ for all the treatments including the control. Chemicals of treatments (6) and (11) were tank mixed immediately before spraying. The yeast spraying solution was prepared according to the method described by Attala et al. (2000) and its chemical analysis was shown in Table (1) according to Ismaeil et al. (2003).

\section{Vegetative growth and yield components}

In order to determine vegetative growth, the length of spring and summer shoots $(\mathrm{cm})$ were measured at mid-June and mid-August of both years. Moreover, the number of fruits at spraying date, before June drop and at harvest time was recorded.The percentage of fruit retention before June drop, after June drop and at 
harvest time was calculated during both seasons. The yield ( number of fruits /tree and $\mathrm{kg} /$ tree) was calculated then calculated the percentage increase in yield compared to control, as the control $100 \%$ yield (yield increament) during both years at harvest date (mid-October).

\section{Fruit physico-chemical characteristics}

In order to determine fruit quality characters, a random sample of five fruits was taken from each replicate. Fruit total acidity, vitamin $\mathrm{C}$, skin carotenoids and total tannins contents were determined according to AOAC (1990). Fruit weight (g) and total soluble solids percent (TSS \% by hand refractometer) were determined. In addition, total sugars were estimated with the method outlined by Malik and Singh (1980), while reducing sugars was determined colourmetrically according to Nelson (1944) and non-reduced sugars were calculated.

\section{Statistical analysis}

All obtained data were subjected to analysis of variance according to Steel and Torrie (1980) and means were differentiated using least significant differences test (LSD) at $5(\%)$ level of probability.

Table 1. Chemical analysis of activated dry yeast $(\mathrm{mg} / 100 \mathrm{~g}$ dry weight).

\begin{tabular}{llllll}
\hline Minerals & & Amino acids & \multicolumn{3}{l}{ Vitamins } \\
\hline Total N & 7.23 & Arginine & 1.99 & Thiamin & 2.71 \\
$\mathrm{P}_{2} \mathrm{O}_{5}$ & 51.68 & Histidine & 2.63 & Riboflavin & 4.96 \\
$\mathrm{~K}_{2} \mathrm{O}$ & 34.39 & Isoleiucine & 2.31 & Nicotinic acid & 39.88 \\
$\mathrm{Na}_{2} \mathrm{O}$ & 0.35 & Leucine & 3.09 & Pantothenic acid & 19.56 \\
$\mathrm{MgO}$ & 5.76 & Lysine & 2.95 & Biotin & 0.09 \\
$\mathrm{CaO}$ & 3.05 & Methionine & 0.72 & Pyridoxine & 2.90 \\
$\mathrm{SiO}_{2}$ & 1.55 & Phenylalanine & 2.01 & Folic acid & 4.36 \\
$\mathrm{SO}_{2}$ & 0.49 & Threonine & 2.09 & Cobalamin & $153 \mu \mathrm{g}$ \\
$\mathrm{NaCl}_{\mathrm{Fe}}$ & 0.30 & Tryptophan & 0.45 & \multicolumn{2}{c}{ Enzymes } \\
$\mathrm{Ba}$ & 0.92 & Valine & 2.19 & Cytochrome oxidase & 0.350 \\
$\mathrm{Co}$ & 175.6 & Glutamic acid & 2.00 & Cytochrome peroxidase & 0.290 \\
$\mathrm{~Pb}$ & 67.8 & Serine & 1.59 & Catalase & 0.063 \\
$\mathrm{Mn}$ & 438.6 & Aspartic acid & 1.33 & & \\
$\mathrm{Sn}$ & 81.3 & Cystine & 0.23 & & 23.20 \\
$\mathrm{Zn}$ & 223.9 & Proline & 1.53 & & \\
\cline { 5 - 6 } & 335.6 & Tyrosine & 1.49 & \multicolumn{2}{c}{ Carbohydrates } \\
\end{tabular}

\section{Results and Discussion}

\section{Effect of chemicals on the fruit physiological stages}

Vegetative growth and yield components

The data presented in Table (2) indicated that all the chemical treatments significantly increased spring and shoot length when compared with the control trees in both seasons. In addition, in comparison among the sprayed compounds, spraying urea and gibberellic acid gave the highest increase in shoot length without significant difference among them in both seasons. The previous results are in line with those reported by El-Shaikh et al. (1999). They sprayed "Costata" persimmon trees with $\mathrm{GA}_{4}$ at 20 ppm + NAA at $10 \mathrm{ppm}$ and indicated that this treatment was the most effective in increasing shoot length. Also, Wally et al. (2004) reported an increase in the vegetative growth of "Anna" apple by spraying activated dry yeast and $\mathrm{GA}_{4}$, respectively. Dutta and Banik (2007) revealed that foliar feeding of nutrients and 
plant growth regulators significantly increased crop yield. The various positive effects of applying activated dry yeast might refer to its content of different nutrients, higher percentage of proteins, larger amount of vitamin B and the natural plant growth regulator such as cytokinins (Ismaeil et al., 2003). The high increase of vegetative growth due to urea sprays might be attributed to that the nitrogenous source involves in proteins, lipids, chlorophyll molecules and nucleic acids biosynthesis thus stimulates vegetative growth. Also, $\mathrm{GA}_{3}$ was found to increase stem length as a result of enhancing cell elongation (Goodwin and Mercer, 1983).

With regard to the fruit physiological stage, the data in Table (2) revealed that in both years foliar sprays at the pea + marble stages gave a significant higher increase in spring and summer shoot length than the sprays at any of the stages alone. Similarly, El-Sabagh and Mostafa (2003) found that spraying "Anna" apple trees, 6 and 16 weeks after full bloom increased the vegetative growth.

The data in Table (2) indicated that, all the treatments significantly increased fruit retention before June drop and at harvest time (except potassium nitrate in the second season) as compared with the control in both seasons. In addition, foliar sprays of gibberellic acid $\left(\mathrm{GA}_{4}\right)$ gave the highest values of fruit retention in comparison with the other foliar treatments in both seasons. A positively high increase in persimmon fruit retention by $\mathrm{GA}_{4}$ sprays was also recorded by Kabeel (1999) and Wally et al. (1999). GA intensifies an organ ability to function as a nutrient sink ,it also increases the biosynthesis of IAA in plant tissues which delays the formation of the separation layer (Wasfy, 1995), thus, enhancing fruit retention.

With regard to the effect of fruit growth stage only, the obtained data showed that foliar sprays at the pea + marble stages gave higher retention value than pea or marble stages alone in both seasons. The previous results agreed with those of Eissa et al. (2007), who reported that spraying pear trees after fruit set and four weeks later increased fruit retention.

With regard to the sprayed compounds only, the data presented in Table (2) indicated that, all treatments increased fruit yield (fruit number per tree) as compared with the control in the two consecutive seasons (except $\mathrm{Ch} . \mathrm{Fe}+\mathrm{Ch}$. $\mathrm{Zn}+$ boric acid in the first season). Moreover, foliar sprays of $\mathrm{GA}_{4}$ and Amcotone recorded the highest number of fruits per tree without significant difference between them in the first season only, while $\mathrm{GA}_{4}$ only recorded the highest value in the second season. In addition, all foliar sprays significantly increased fruit yield as $\mathrm{Kg}$ per tree in comparison with the control in both seasons. $\mathrm{GA}_{4}$ gave the highest value of fruit weight per tree in both seasons. These results are in conformity with those of Blumenfeld (1986), El-Shaikh et al. (1999) and Kabeel (1999). They found that, spraying persimmon trees with $\mathrm{GA}_{3}$, NAA and promalin increased fruit yield. Similar results were obtained by Fathi et al. (1999) who sprayed "Anna" apple trees with $\left(\mathrm{GA}_{4}\right.$ $\left.+\mathrm{GA}_{7}\right)$. Moore (1979) stated that the stimulation of both cell division and cell enlargement due to $\mathrm{GA}_{4}$ foliar sprays is surely reflected on increasing fruit weight, consequently fruit yield. Moreover, Westwood (1978) stated that yield increment of deciduous fruit trees was attributed to the depressing of fruit drop percent caused by the application of auxins and gibberellins. Attala et al. (2000) indicated that, the various positive effects of spraying active dry yeast, as newly used bio stimulant were attributed to its content of different nutrients, higher percentage of proteins, larger amount of vitamin B and the natural plant growth hormones namely cytokinins. Also, they noticed that, spraying active dry yeast was very effective in releasing $\mathrm{CO}_{2}$ which reflected on improving net photosynthesis. Hossain 
and Ryu (2009) reported that the foliar application of phosphatic fertilizer increased the vegetative growth, number of effective flowering buds of sweet persimmon over control. Sweet persimmon yield increased due to the fact of decreasing trend of fruit dropping by foliar fertilization.
With regard to the fruit growth stage alone, the data presented in Table (2) indicated that, foliar sprays at pea + marble stages gave the highest number and weight of fruits per tree than spraying at any of the stages alone in both seasons.

Table 2. The mean effect of chemical treatments and physiological stages on vegetative growth, fruit retention, fruit drop and yield of Costata persimmon trees during 2006 and 2007 years.

\begin{tabular}{|c|c|c|c|c|c|c|}
\hline \multirow[b]{2}{*}{ Treatments } & \multicolumn{2}{|c|}{ Shoot length (cm) } & \multicolumn{2}{|c|}{ Fruit retention (\%) } & \multicolumn{2}{|c|}{ Yield increment (\%) } \\
\hline & Spring & Summer & $\begin{array}{l}\text { Before } \\
\text { June drop }\end{array}$ & $\begin{array}{l}\text { At harvest } \\
\text { date }\end{array}$ & $\begin{array}{l}\text { No.of fruits } \\
\text { / tree }\end{array}$ & $\begin{array}{l}\text { kg } \\
/ \text { tree }\end{array}$ \\
\hline \multicolumn{7}{|l|}{2006} \\
\hline T1 & 25.40 & 16.56 & 44.54 & 23.23 & 100 & 100 \\
\hline $\mathrm{T} 2$ & 42.79 & 33.09 & 58.72 & 26.86 & 141 & 175 \\
\hline T3 & 34.16 & 24.73 & 62.66 & 27.13 & 144 & 176 \\
\hline $\mathrm{T} 4$ & 37.33 & 28.52 & 52.94 & 24.80 & 123 & 141 \\
\hline T5 & 28.40 & 18.93 & 63.20 & 30.79 & 145 & 176 \\
\hline T6 & 31.21 & 21.69 & 50.88 & 25.16 & 113 & 172 \\
\hline $\mathrm{T} 7$ & 35.60 & 26.50 & 64.01 & 33.98 & 158 & 211 \\
\hline T8 & 42.14 & 31.91 & 80.76 & 54.40 & 210 & 290 \\
\hline Т9 & 34.40 & 24.18 & 75.27 & 44.15 & 196 & 283 \\
\hline $\mathrm{T} 10$ & 32.51 & 23.78 & 68.09 & 35.80 & 158 & 281 \\
\hline T11 & 30.17 & 22.17 & 54.67 & 26.60 & 131 & 210 \\
\hline L.S.D ${ }_{0.05}$ & 2.29 & 1.55 & 2.54 & 0.64 & 22 & 40 \\
\hline \multicolumn{7}{|c|}{ Physiological stages } \\
\hline Stage 1 & 33.08 & 23.37 & 59.93 & 30.98 & 100 & 100 \\
\hline Stage 2 & 33.00 & 24.10 & 60.58 & 31.28 & 105 & 102 \\
\hline Stage 3 & 35.95 & 26.72 & 63.78 & 33.99 & 120 & 140 \\
\hline L.S.D ${ }_{0.05}$ & 1.15 & 0.77 & 0.82 & 0.24 & 4 & 6 \\
\hline \multicolumn{7}{|l|}{2007} \\
\hline T1 & 26.16 & 16.34 & 43.32 & 23.62 & 100 & 100 \\
\hline $\mathrm{T} 2$ & 43.67 & 33.12 & 58.62 & 26.56 & 148 & 152 \\
\hline $\mathrm{T} 3$ & 35.27 & 24.28 & 62.46 & 26.95 & 152 & 156 \\
\hline $\mathrm{T} 4$ & 38.14 & 28.42 & 52.74 & 24.76 & 132 & 118 \\
\hline T5 & 30.32 & 19.47 & 63.11 & 30.97 & 172 & 190 \\
\hline T6 & 32.53 & 20.70 & 50.68 & 25.21 & 124 & 116 \\
\hline $\mathrm{T} 7$ & 36.07 & 26.88 & 63.81 & 34.09 & 168 & 229 \\
\hline T8 & 43.69 & 31.93 & 80.56 & 54.56 & 236 & 337 \\
\hline T9 & 37.00 & 24.16 & 75.16 & 44.11 & 216 & 308 \\
\hline $\mathrm{T} 10$ & 33.92 & 23.07 & 67.89 & 35.84 & 176 & 266 \\
\hline $\mathrm{T} 11$ & 31.78 & 22.17 & 54.48 & 26.77 & 140 & 156 \\
\hline L.S.D $D_{0.05}$ & 2.20 & 2.12 & 2.62 & 1.27 & 21 & 43 \\
\hline \multicolumn{7}{|c|}{ Physiological stages } \\
\hline Stage 1 & 34.06 & 23.53 & 59.38 & 30.87 & 100 & 100 \\
\hline Stage 2 & 34.37 & 23.77 & 61.48 & 31.33 & 109 & 110 \\
\hline Stage 3 & 37.54 & 26.48 & 62.64 & 34.20 & 137 & 142 \\
\hline L.S.D 0.05 & 0.73 & 0.53 & 0.79 & 0.25 & 3 & 5 \\
\hline
\end{tabular}


These results are in general agreement with those of Abd El-Wahab et al. (1999) working on "Anna" apple trees and Kabeel and Saadany (2004) working on "Le-Conte" pear trees. Also, He Wei Hua et al. (1998) stated that, spraying apple trees twice, 21 and 35 days after flowering with calcium nitrate increased fruit number per tree.

\section{Fruit physico-chemical characteristics}

With regard to the sprayed substances only on fruit weight, the data of both seasons presented in Table (3) indicated that, all sprayed substances significantly increased fruit weight when compared with the control in both seasons. In additions, foliar sprays of $\mathrm{GA}_{4}$ recorded the highest values in comparison with the other substances in both seasons. These results are in line with those of El-Shaikh et al. (1999). They stated that spraying "Costata" persimmon trees with $\mathrm{GA}_{3}$ and NAA significantly increased fruit weight. Also, Kabeel (1999) stated that spraying "Costata" persimmon trees with GA3 and Promalin increased fruit weight. Similarly, Ismaeil et al. (2003) stated that spraying "Thompson seedless" and "Romi Red" grape vines with $\mathrm{GA}_{3}$ and active dry yeast increased berry and cluster weight. The increase in fruit size might be attributed to the increase in cell division and cell elongation caused by auxins and $\mathrm{GA}_{3}$ (Cleland, 1995; Ranjan et al., 2003). In addition, active dry yeast contains tryptophan which is a precursor of IAA, thus, encourages the production of IAA that is known to play an important role in cell division (Moore, 1979). Furthermore, Ahmed et al. (1998) reported that ascorbic and citric acids as natural organic antioxidants compounds have an auxinic action and synergistic effect on improving fruit size in "Anna" apple trees.

With regard to the fruit growth stage, foliar sprays at pea + marble stages gave the highest fruit weight in both seasons when comparing with spraying at the pea or marble stage alone. These results agreed with those of Eliwa et al. (2003) on persimmon, Youn et al. (2004) on apple and Kabeel and El-Saadany (2004) on pear trees.

In accordance to sprayed substances only on fruit chemical quality, the data of both seasons presented in Table (3) indicated that, in general, all the sprayed compounds significantly increased TSS, total sugars, reducing sugars, carotene, and vitamin " $C$ " contents as compared with the control. The foliar sprays of phosphoric acid recorded the highest value of TSS, total sugars, reducing sugars and carotene contents in both seasons as compared with all other treatments. Whereas, activated dry yeast gave significantly higher vitamin "C" and lower tannins contents than all other treatments. Moreover, non-reducing sugars were significantly decreased by spraying phosphoric acid, potassium nitrate, chelated calcium, Amcotone and activated dry yeast in both seasons. These results are in line with those obtained by Eliwa et al. (2003), using potassium phosphate and potassium citrate, Attala et al. (2000) and Hassan (2002) using activated dry yeast and Alina (1998) using NAA foliar sprays. In this aspec, Hassona (1967) stated that, phosphoric acid has a major role in the biosynthesis of nucleic acid, ATP molecules, and acts as coenzyme for many enzymes. Also, he noticed that, potassium promotes starch transformation into saccharides in plant cells. Similarly, Wignarjah (1995) reported that, potassium is known to be important in activation of many enzymes of intermediary metabolism and biosynthesis. Moreover, Attala et al. (2000) indicated that activated dry yeast was very effective in releasing $\mathrm{CO}_{2}$ that leads to improve net photosynthesis. From the previous mentioned, the beneficial influences of phosphoric acid, potassium and activated dry yeast might explain their influence in enhancing fruit quality. 
Table 3. The mean effect of chemical treatments and physiological stages on fruit quality characters of Costata persimmon trees during 2006 and 2007 years.

\begin{tabular}{|c|c|c|c|c|c|c|c|c|c|}
\hline Treatments & $\underbrace{\frac{D}{000}}_{0}$ & $\begin{array}{l}\text { TSS } \\
(\%)\end{array}$ & 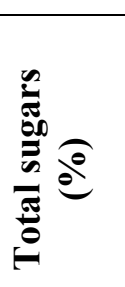 & 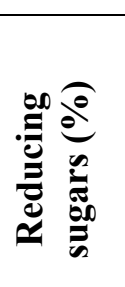 & 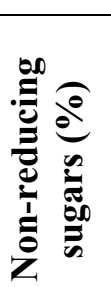 & 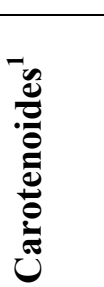 & & V.C $\mathbf{C}^{3}$ & $\frac{3}{2}$ \\
\hline \multicolumn{10}{|l|}{2006} \\
\hline $\mathrm{T} 1$ & 86.43 & 19.01 & 14.38 & 11.19 & 3.26 & 2.58 & 3.26 & 9.8 & 0.49 \\
\hline $\mathrm{T} 2$ & 122.81 & 21.99 & 14.67 & 11.66 & 3.01 & 2.64 & 2.19 & 17.1 & 0.18 \\
\hline T3 & 127.04 & 27.65 & 17.66 & 15.56 & 2.09 & 4.83 & 1.83 & 12.3 & 0.18 \\
\hline T4 & 122.80 & 26.67 & 17.01 & 14.74 & 2.27 & 2.90 & 2.41 & 11.1 & 0.51 \\
\hline T5 & 117.58 & 24.84 & 15.54 & 12.70 & 2.84 & 2.80 & 2.77 & 15.5 & 0.16 \\
\hline T6 & 118.27 & 24.52 & 15.50 & 12.54 & 2.96 & 3.33 & 2.47 & 13.7 & 0.17 \\
\hline T7 & 146.17 & 23.35 & 15.25 & 12.06 & 3.18 & 2.65 & 2.19 & 12.6 & 0.34 \\
\hline T8 & 182.44 & 22.11 & 14.76 & 11.65 & 3.11 & 2.73 & 2.03 & 11.4 & 0.40 \\
\hline T9 & 153.97 & 25.07 & 15.71 & 13.50 & 2.20 & 2.67 & 1.93 & 12.9 & 0.26 \\
\hline T10 & 170.14 & 25.93 & 16.42 & 14.28 & 2.17 & 4.42 & 1.65 & 20.1 & 0.37 \\
\hline T11 & 162.96 & 24.06 & 15.22 & 12.17 & 3.05 & 3.39 & 1.84 & 14.6 & 0.21 \\
\hline L.S.D ${ }_{0.05}$ & 3.40 & 0.77 & 0.27 & 0.16 & 0.31 & 0.34 & 0.15 & 0.34 & 0.06 \\
\hline \multicolumn{10}{|c|}{ Physiological stages } \\
\hline Stage 1 & 129.17 & 23.83 & 15.52 & 12.76 & 2.76 & 3.02 & 2.29 & 13.4 & 0.32 \\
\hline Stage 2 & 135.37 & 23.91 & 15.50 & 12.86 & 2.64 & 3.11 & 2.27 & 13.6 & 0.31 \\
\hline Stage 3 & 147.45 & 24.60 & 15.92 & 13.12 & 2.82 & 3.39 & 2.14 & 14.3 & 0.27 \\
\hline L.S.D 0.05 & 1.47 & 0.19 & 0.09 & 0.07 & 0.14 & 0.10 & 0.06 & 0.17 & 0.02 \\
\hline \multicolumn{10}{|l|}{2007} \\
\hline $\mathrm{T} 1$ & 83.44 & 18.95 & 14.38 & 11.20 & 3.18 & 2.42 & 3.27 & 9.8 & 0.51 \\
\hline $\mathrm{T} 2$ & 120.18 & 22.15 & 14.69 & 11.65 & 3.04 & 2.68 & 2.21 & 17.0 & 0.18 \\
\hline T3 & 123.78 & 28.14 & 17.69 & 15.49 & 2.20 & 4.75 & 1.87 & 12.4 & 0.17 \\
\hline T4 & 119.69 & 26.70 & 17.01 & 14.79 & 2.22 & 3.01 & 2.42 & 11.2 & 0.50 \\
\hline T5 & 116.69 & 24.94 & 15.56 & 12.65 & 2.90 & 2.80 & 2.67 & 15.4 & 0.16 \\
\hline T6 & 115.14 & 24.66 & 15.51 & 12.52 & 2.99 & 3.32 & 2.41 & 13.8 & 0.15 \\
\hline $\mathrm{T} 7$ & 150.18 & 23.69 & 15.30 & 12.13 & 3.17 & 2.74 & 2.13 & 12.7 & 0.30 \\
\hline T8 & 178.95 & 22.49 & 14.97 & 11.67 & 3.30 & 2.84 & 2.03 & 11.4 & 0.42 \\
\hline T9 & 166.44 & 25.96 & 16.05 & 13.48 & 2.57 & 2.73 & 1.93 & 13.1 & 0.29 \\
\hline $\mathrm{T} 10$ & 159.51 & 26.28 & 16.49 & 14.19 & 2.30 & 4.55 & 1.60 & 19.9 & 0.27 \\
\hline $\mathrm{T} 11$ & 138.53 & 24.02 & 15.49 & 12.15 & 3.34 & 3.45 & 1.75 & 14.8 & 0.19 \\
\hline L.S.D ${ }_{0.05}$ & 4.55 & 0.98 & 0.51 & 0.22 & 0.47 & 0.41 & 0.20 & 0.41 & 0.05 \\
\hline \multicolumn{10}{|c|}{ Physiological stages } \\
\hline Stage 1 & 126.85 & 24.00 & 15.56 & 12.73 & 2.83 & 3.00 & 2.27 & 13.4 & 0.31 \\
\hline Stage 2 & 131.29 & 24.01 & 15.56 & 12.98 & 2.75 & 3.12 & 2.26 & 13.5 & 0.29 \\
\hline Stage 3 & 143.46 & 25.26 & 16.10 & 12.99 & 2.94 & 3.50 & 2.09 & 14.3 & 0.25 \\
\hline L.S.D 0.05 & 1.42 & 0.19 & 0.11 & 0.08 & 0.13 & 0.09 & 0.05 & 0.19 & 0.02 \\
\hline
\end{tabular}

1 (mg carotene/100 g F.W.); 2 (mg tannic acid/100 ml fruit juice); 3 (mg ascorbic acid/100 $\mathrm{ml}$ fruit juice); 4 (mg malic acid/100 $\mathrm{ml}$ fruit juice.

The decrease in tannins and acidity contents might be attributed to the increase in fruit volume previously obtained in this study by the same foliar sprays. Also, it might be attributed to the dilution effect in accordance to the increase in water uptake by spraying auxins and $\mathrm{GA}_{3}$ as mentioned by Ranjan et al. (2003).

In the mean time, ascorbic and citric acids were found to have an auxinic action 
(Ahmed et al., 1998), which might explain their influence in decreasing total tannins content.With regard to the effect of the fruit physiological stage only, the data presented in Table (3) revealed that, in general, foliar sprays at pea + marble stages significantly increased fruit TSS, total sugars, reducing sugars, carotene and vitamin "C" contents and decreased fruit acidity and tannin contents when compared with spraying at the pea or marble stage alone. These results agreed with those obtained by Ahmed et al. (1998), Eliwa et al. (2003) and El-Seginy et al. (2003).

Table 4. The interaction effect of chemical treatments and physiological stages on vegetative growth, fruit retention, fruit drop and yield of Costata persimmon trees in 2006 year.

\begin{tabular}{|c|c|c|c|c|c|c|}
\hline \multirow[b]{2}{*}{ Treatments } & \multicolumn{2}{|c|}{ Shoot length (cm) } & \multicolumn{2}{|c|}{ Fruit retention (\%) } & \multicolumn{2}{|c|}{ Yield increament(\%) } \\
\hline & Spring & Summer & $\begin{array}{l}\text { Before June } \\
\text { drop }\end{array}$ & $\begin{array}{l}\text { At harvest } \\
\text { date }\end{array}$ & $\begin{array}{l}\text { No. of fruits } \\
\text { /tree }\end{array}$ & kg/tree \\
\hline \multicolumn{7}{|l|}{ Stage 1} \\
\hline $\mathrm{T} 1$ & 25.40 & 16.80 & 44.50 & 23.24 & 100 & 100 \\
\hline $\mathrm{T} 2$ & 41.30 & 30.97 & 57.38 & 25.88 & 128 & 182 \\
\hline $\mathrm{T} 3$ & 33.73 & 23.17 & 61.31 & 26.20 & 121 & 180 \\
\hline $\mathrm{T} 4$ & 35.47 & 27.33 & 52.01 & 24.05 & 114 & 156 \\
\hline T5 & 27.60 & 18.33 & 61.75 & 29.62 & 145 & 192 \\
\hline T6 & 30.40 & 19.53 & 49.68 & 24.50 & 107 & 135 \\
\hline $\mathrm{T} 7$ & 35.27 & 25.63 & 62.88 & 32.46 & 148 & 231 \\
\hline T8 & 41.47 & 29.60 & 77.42 & 53.16 & 197 & 412 \\
\hline T9 & 32.50 & 23.10 & 73.49 & 41.87 & 186 & 305 \\
\hline T10 & 31.53 & 22.87 & 65.91 & 34.47 & 152 & 300 \\
\hline $\mathrm{T} 11$ & 29.20 & 19.73 & 52.85 & 25.30 & 121 & 230 \\
\hline \multicolumn{7}{|l|}{ Stage 2} \\
\hline $\mathrm{T} 1$ & 25.53 & 16.60 & 44.46 & 22.81 & 100 & 100 \\
\hline $\mathrm{T} 2$ & 41.80 & 32.70 & 58.03 & 26.14 & 143 & 188 \\
\hline $\mathrm{T} 3$ & 33.10 & 23.70 & 61.55 & 26.40 & 143 & 195 \\
\hline $\mathrm{T} 4$ & 34.77 & 28.30 & 52.61 & 24.58 & 125 & 171 \\
\hline T5 & 27.10 & 17.93 & 62.07 & 30.73 & 161 & 208 \\
\hline T6 & 29.79 & 20.90 & 50.76 & 24.42 & 107 & 135 \\
\hline $\mathrm{T} 7$ & 34.47 & 25.93 & 62.78 & 32.93 & 164 & 262 \\
\hline T8 & 40.97 & 31.63 & 79.84 & 53.06 & 207 & 311 \\
\hline T9 & 33.93 & 22.87 & 73.02 & 42.22 & 196 & 321 \\
\hline $\mathrm{T} 10$ & 31.77 & 22.80 & 67.70 & 34.80 & 168 & 306 \\
\hline $\mathrm{T} 11$ & 28.60 & 21.76 & 53.59 & 25.97 & 132 & 231 \\
\hline \multicolumn{7}{|l|}{ Stage 3} \\
\hline $\mathrm{T} 1$ & 25.27 & 16.27 & 44.65 & 23.64 & 100 & 100 \\
\hline $\mathrm{T} 2$ & 45.26 & 35.60 & 60.76 & 28.56 & 162 & 241 \\
\hline $\mathrm{T} 3$ & 35.67 & 27.33 & 65.11 & 28.78 & 173 & 268 \\
\hline $\mathrm{T} 4$ & 41.77 & 29.93 & 54.21 & 25.75 & 135 & 203 \\
\hline T5 & 30.47 & 20.53 & 65.78 & 32.03 & 169 & 250 \\
\hline T6 & 33.27 & 24.63 & 52.18 & 26.56 & 104 & 204 \\
\hline $\mathrm{T} 7$ & 36.07 & 27.93 & 66.35 & 36.55 & 173 & 321 \\
\hline T8 & 44.00 & 24.50 & 85.02 & 56.97 & 242 & 526 \\
\hline T9 & 36.77 & 26.57 & 79.32 & 48.35 & 217 & 444 \\
\hline $\mathrm{T} 10$ & 34.23 & 25.66 & 70.66 & 38.14 & 190 & 394 \\
\hline $\mathrm{T} 11$ & 32.73 & 25.00 & 57.57 & 28.54 & 142 & 285 \\
\hline L.S.D ${ }_{0.05}$ & N.S & N.S & N.S & 0.81 & 15 & 24 \\
\hline
\end{tabular}


Effect of chemicals and physiological stages interaction

Vegetative growth and yield components

With regard to the interaction effect between the different sprayed substances and the fruit physiological growth stages, the data presented in Tables (4 and 5) showed no significant interaction effect obtained in both seasons regarding spring and summer shoot length.

Table 5. The interaction effect of chemical treatments and physiological stages on vegetative growth, fruit retention, fruit drop and yield of Costata persimmon trees in 2007 year.

\begin{tabular}{|c|c|c|c|c|c|c|}
\hline \multirow[b]{2}{*}{ Treatments } & \multicolumn{2}{|c|}{ Shoot length $(\mathrm{cm})$} & \multicolumn{2}{|c|}{ Fruit retention (\%) } & \multicolumn{2}{|c|}{ Yield increament(\%) } \\
\hline & Spring & Summer & $\begin{array}{l}\text { Before June } \\
\text { drop }\end{array}$ & $\begin{array}{l}\text { At harvest } \\
\text { date }\end{array}$ & $\begin{array}{l}\text { No. of fruits } \\
\text { /tree }\end{array}$ & $\mathrm{kg} /$ tree \\
\hline \multicolumn{7}{|l|}{ Stage 1} \\
\hline T1 & 26.30 & 16.60 & 43.37 & 23.55 & 100 & 100 \\
\hline $\mathrm{T} 2$ & 42.00 & 31.30 & 57.29 & 25.72 & 132 & 190 \\
\hline $\mathrm{T} 3$ & 34.43 & 23.13 & 58.77 & 26.11 & 124 & 178 \\
\hline $\mathrm{T} 4$ & 35.60 & 27.53 & 51.42 & 23.32 & 120 & 159 \\
\hline T5 & 29.10 & 18.67 & 60.98 & 29.78 & 156 & 209 \\
\hline T6 & 31.63 & 19.40 & 49.22 & 24.39 & 108 & 139 \\
\hline $\mathrm{T} 7$ & 35.60 & 26.17 & 60.60 & 32.46 & 152 & 246 \\
\hline $\mathrm{T} 8$ & 42.00 & 30.40 & 79.10 & 52.50 & 212 & 445 \\
\hline T9 & 35.07 & 23.07 & 74.60 & 42.12 & 200 & 388 \\
\hline $\mathrm{T} 10$ & 32.40 & 21.97 & 64.80 & 34.04 & 160 & 301 \\
\hline $\mathrm{T} 11$ & 30.50 & 20.63 & 53.02 & 25.53 & 124 & 193 \\
\hline \multicolumn{7}{|l|}{ Stage 2} \\
\hline $\mathrm{T} 1$ & 25.73 & 16.43 & 42.68 & 23.59 & 100 & 100 \\
\hline $\mathrm{T} 2$ & 42.33 & 32.17 & 57.42 & 25.55 & 155 & 213 \\
\hline $\mathrm{T} 3$ & 34.33 & 22.60 & 62.93 & 26.08 & 151 & 216 \\
\hline $\mathrm{T} 4$ & 36.33 & 27.90 & 53.39 & 24.25 & 134 & 187 \\
\hline T5 & 28.67 & 18.80 & 64.85 & 30.10 & 172 & 230 \\
\hline T6 & 31.03 & 19.70 & 50.46 & 23.99 & 126 & 163 \\
\hline $\mathrm{T} 7$ & 35.97 & 26.17 & 65.08 & 33.24 & 172 & 284 \\
\hline $\mathrm{T} 8$ & 43.07 & 31.03 & 79.02 & 53.72 & 235 & 495 \\
\hline T9 & 36.30 & 23.07 & 73.78 & 42.99 & 214 & 406 \\
\hline $\mathrm{T} 10$ & 33.50 & 22.17 & 70.01 & 34.98 & 172 & 310 \\
\hline $\mathrm{T} 11$ & 30.67 & 21.43 & 56.67 & 26.11 & 143 & 225 \\
\hline \multicolumn{7}{|l|}{ Stage 3} \\
\hline $\mathrm{T} 1$ & 26.43 & 16.00 & 43.90 & 23.70 & 100 & 100 \\
\hline $\mathrm{T} 2$ & 46.67 & 35.90 & 61.16 & 28.43 & 155 & 231 \\
\hline $\mathrm{T} 3$ & 36.91 & 27.10 & 65.67 & 28.65 & 174 & 274 \\
\hline $\mathrm{T} 4$ & 42.50 & 29.83 & 53.42 & 26.71 & 133 & 205 \\
\hline T5 & 33.20 & 20.93 & 63.50 & 33.05 & 178 & 268 \\
\hline T6 & 34.93 & 23.00 & 52.36 & 27.26 & 140 & 209 \\
\hline $\mathrm{T} 7$ & 36.63 & 28.30 & 65.74 & 36.58 & 170 & 357 \\
\hline $\mathrm{T} 8$ & 46.00 & 34.37 & 83.55 & 57.45 & 252 & 553 \\
\hline T9 & 39.63 & 26.33 & 77.11 & 47.21 & 222 & 466 \\
\hline $\mathrm{T} 10$ & 35.87 & 25.07 & 68.86 & 38.49 & 185 & 377 \\
\hline $\mathrm{T} 11$ & 34.17 & 24.43 & 53.73 & 28.66 & 148 & 271 \\
\hline L.S.D 0.05 & N.S & N.S & 2.62 & 0.84 & 17 & 31 \\
\hline
\end{tabular}


Emir. J. Food Agric. 2010. 22 (4): 259-274

http://ffa.uaeu.ac.ae/ejfa.shtml

Table 6. The interaction effect of chemical treatments and physiological stages on fruit quality characters of Costata persimmon trees in 2006 year.

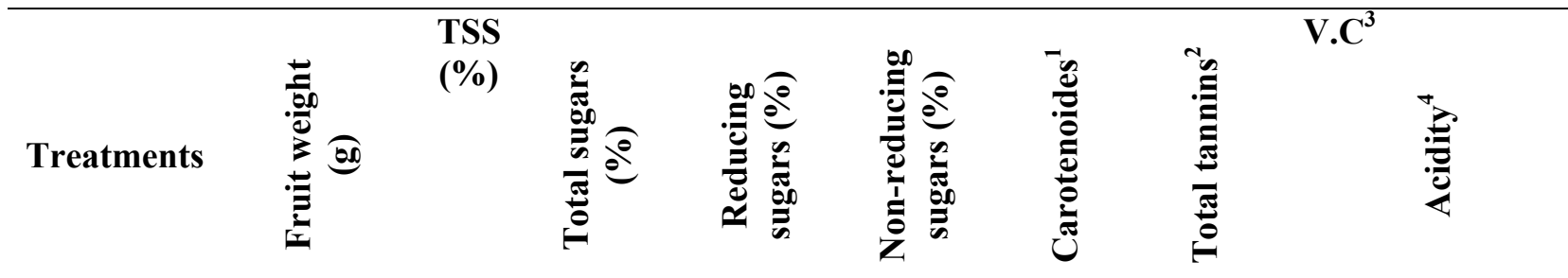

\begin{tabular}{|c|c|c|c|c|c|c|c|c|c|}
\hline \multicolumn{10}{|l|}{ Stage 1} \\
\hline $\mathrm{T} 1$ & 83.70 & 19.03 & 14.23 & 11.18 & 3.05 & 2.49 & 3.26 & 9.7 & 0.49 \\
\hline $\mathrm{T} 2$ & 120.15 & 21.41 & 14.34 & 11.62 & 2.72 & 2.61 & 2.29 & 16.1 & 0.19 \\
\hline T3 & 122.79 & 27.42 & 17.54 & 15.01 & 2.53 & 4.55 & 1.89 & 12.1 & 0.19 \\
\hline $\mathrm{T} 4$ & 113.91 & 26.57 & 16.89 & 14.49 & 2.39 & 2.75 & 2.48 & 11.0 & 0.57 \\
\hline T5 & 107.06 & 24.42 & 15.31 & 12.62 & 2.69 & 2.71 & 2.75 & 15.1 & 0.14 \\
\hline T6 & 107.66 & 24.11 & 15.46 & 12.43 & 3.03 & 3.11 & 2.53 & 13.3 & 0.17 \\
\hline $\mathrm{T} 7$ & 131.22 & 22.85 & 15.21 & 11.97 & 3.24 & 2.61 & 2.25 & 12.4 & 0.35 \\
\hline T8 & 157.76 & 21.73 & 14.65 & 11.67 & 2.98 & 2.49 & 2.09 & 11.0 & 0.44 \\
\hline T9 & 136.90 & 25.09 & 15.64 & 13.31 & 2.33 & 2.58 & 2.03 & 12.7 & 0.33 \\
\hline T10 & 163.99 & 25.81 & 16.28 & 14.08 & 2.20 & 4.13 & 1.74 & 19.1 & 0.39 \\
\hline T11 & 157.72 & 23.69 & 15.16 & 11.95 & 3.21 & 3.21 & 1.96 & 14.4 & 0.21 \\
\hline \multicolumn{10}{|l|}{ Stage 2} \\
\hline $\mathrm{T} 1$ & 89.53 & 19.00 & 14.51 & 11.21 & 3.30 & 2.61 & 3.27 & 9.9 & 0.49 \\
\hline $\mathrm{T} 2$ & 120.96 & 21.65 & 14.69 & 11.53 & 3.15 & 2.67 & 2.22 & 17.1 & 0.18 \\
\hline T3 & 124.76 & 27.68 & 17.23 & 15.72 & 1.49 & 4.65 & 1.84 & 12.2 & 0.19 \\
\hline T4 & 123.03 & 26.32 & 16.87 & 14.61 & 2.26 & 3.08 & 2.49 & 10.4 & 0.50 \\
\hline T5 & 117.31 & 24.67 & 15.33 & 12.67 & 2.66 & 2.73 & 2.87 & 15.4 & 0.19 \\
\hline T6 & 114.91 & 24.41 & 15.27 & 12.52 & 2.75 & 3.19 & 2.56 & 13.7 & 0.17 \\
\hline $\mathrm{T} 7$ & 145.52 & 23.08 & 15.18 & 12.01 & 3.17 & 2.63 & 2.21 & 12.5 & 0.38 \\
\hline T8 & 182.89 & 21.67 & 14.62 & 11.38 & 3.24 & 2.71 & 2.09 & 11.4 & 0.39 \\
\hline T9 & 147.69 & 24.85 & 15.31 & 13.40 & 1.91 & 2.51 & 1.90 & 12.6 & 0.24 \\
\hline $\mathrm{T} 10$ & 166.49 & 25.66 & 16.33 & 14.22 & 2.11 & 4.26 & 1.64 & 19.9 & 0.41 \\
\hline T11 & 155.98 & 23.96 & 15.18 & 12.19 & 2.99 & 3.20 & 1.83 & 14.5 & 0.22 \\
\hline \multicolumn{10}{|l|}{ Stage 3} \\
\hline $\mathrm{T} 1$ & 86.05 & 19.01 & 14.39 & 11.18 & 3.42 & 2.65 & 3.26 & 9.9 & 0.51 \\
\hline $\mathrm{T} 2$ & 127.32 & 22.90 & 14.98 & 11.83 & 3.14 & 2.62 & 2.06 & 18.0 & 0.16 \\
\hline T3 & 133.57 & 27.86 & 18.20 & 15.95 & 2.25 & 5.29 & 1.76 & 12.7 & 0.14 \\
\hline T4 & 131.48 & 27.13 & 17.27 & 15.11 & 2.16 & 2.88 & 2.25 & 11.8 & 0.46 \\
\hline T5 & 128.35 & 25.43 & 15.99 & 12.82 & 3.77 & 2.97 & 2.70 & 15.8 & 0.16 \\
\hline T6 & 132.24 & 25.03 & 15.76 & 12.65 & 3.11 & 3.69 & 2.31 & 14.2 & 0.16 \\
\hline $\mathrm{T} 7$ & 161.77 & 24.14 & 15.36 & 12.22 & 3.12 & 2.72 & 2.11 & 13.1 & 0.28 \\
\hline T8 & 188.68 & 22.93 & 15.01 & 11.89 & 3.12 & 2.97 & 1.93 & 11.9 & 0.36 \\
\hline T9 & 177.33 & 25.28 & 16.17 & 13.80 & 2.37 & 2.92 & 1.87 & 13.4 & 0.20 \\
\hline T10 & 179.96 & 26.32 & 16.67 & 14.48 & 2.19 & 4.87 & 1.57 & 21.4 & 0.30 \\
\hline T11 & 157.18 & 24.53 & 15.33 & 12.39 & 2.95 & 3.76 & 1.74 & 15.1 & 0.19 \\
\hline L.S.D 0.05 & 4.87 & N.S & 0.31 & 0.23 & 0.48 & 0.33 & N.S & 0.67 & N.S \\
\hline
\end{tabular}


Table 7. The interaction effect of chemical treatments and physiological stages on fruit quality characters of Costata persimmon trees in 2007 year.

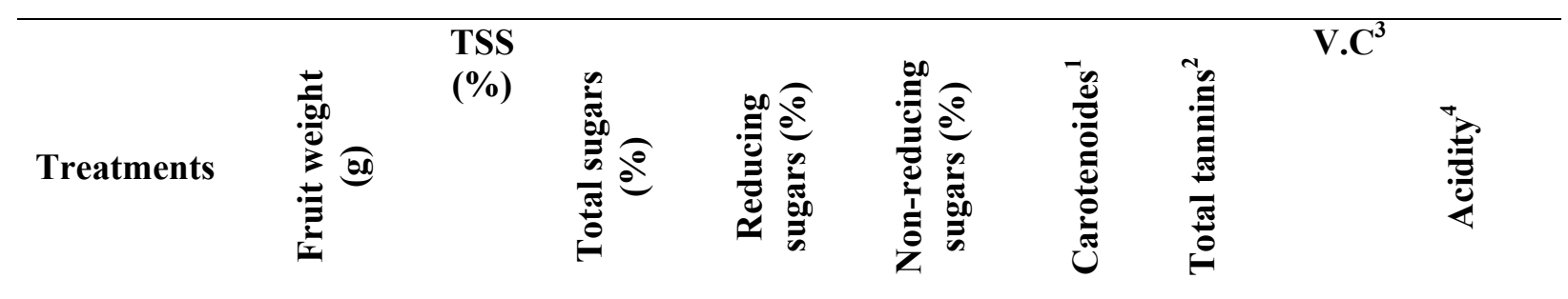

\begin{tabular}{|c|c|c|c|c|c|c|c|c|c|}
\hline Stage 1 & & & & & & & & & \\
\hline $\mathrm{T} 1$ & 82.53 & 18.85 & 14.37 & 11.20 & 3.17 & 2.33 & 3.26 & 9.7 & 0.49 \\
\hline $\mathrm{T} 2$ & 117.64 & 21.60 & 14.34 & 11.59 & 2.74 & 2.63 & 2.31 & 16.3 & 0.20 \\
\hline $\mathrm{T} 3$ & 119.49 & 28.02 & 17.52 & 15.02 & 2.51 & 4.52 & 1.90 & 12.2 & 0.20 \\
\hline T4 & 111.58 & 26.61 & 16.86 & 14.41 & 2.45 & 2.75 & 2.50 & 11.0 & 0.58 \\
\hline T5 & 110.12 & 24.57 & 15.34 & 12.55 & 2.79 & 2.67 & 2.65 & 15.0 & 0.16 \\
\hline T6 & 104.88 & 24.14 & 15.43 & 12.37 & 3.06 & 3.08 & 2.49 & 13.5 & 0.18 \\
\hline $\mathrm{T} 7$ & 134.44 & 22.93 & 15.16 & 12.15 & 3.16 & 2.61 & 2.20 & 12.4 & 0.29 \\
\hline T8 & 172.31 & 21.98 & 14.85 & 11.57 & 3.16 & 2.49 & 2.04 & 11.0 & 0.46 \\
\hline T9 & 160.63 & 25.95 & 15.85 & 13.32 & 2.53 & 2.54 & 2.01 & 13.0 & 0.35 \\
\hline T10 & 153.91 & 25.93 & 16.17 & 13.90 & 2.17 & 4.14 & 1.71 & 19.2 & 0.34 \\
\hline T11 & 127.85 & 23.54 & 15.29 & 11.98 & 3.36 & 3.26 & 1.88 & 14.4 & 0.20 \\
\hline \multicolumn{10}{|l|}{ Stage 2} \\
\hline $\mathrm{T} 1$ & 84.11 & 18.97 & 14.34 & 11.19 & 3.16 & 2.44 & 3.29 & 9.8 & 0.53 \\
\hline $\mathrm{T} 2$ & 118.74 & 21.47 & 14.68 & 11.47 & 3.22 & 2.67 & 2.24 & 16.9 & 0.19 \\
\hline T3 & 121.56 & 27.99 & 17.35 & 15.50 & 1.85 & 4.46 & 1.91 & 12.2 & 0.17 \\
\hline T4 & 119.78 & 26.11 & 16.90 & 14.17 & 2.28 & 2.98 & 2.50 & 10.9 & 0.51 \\
\hline T5 & 114.86 & 24.65 & 15.34 & 12.58 & 2.79 & 2.73 & 2.84 & 15.3 & 0.18 \\
\hline T6 & 111.99 & 24.47 & 15.17 & 12.48 & 2.69 & 3.27 & 2.49 & 13.6 & 0.15 \\
\hline T7 & 142.61 & 23.39 & 15.13 & 12.29 & 3.04 & 2.66 & 2.15 & 12.4 & 0.33 \\
\hline T8 & 179.74 & 21.91 & 14.72 & 11.87 & 3.30 & 2.89 & 2.12 & 11.3 & 0.43 \\
\hline Т9 & 162.68 & 25.37 & 15.82 & 13.90 & 2.45 & 2.55 & 1.98 & 12.8 & 0.30 \\
\hline T10 & 153.50 & 25.99 & 16.38 & 14.54 & 2.28 & 4.31 & 1.62 & 19.1 & 0.26 \\
\hline T11 & 134.60 & 23.55 & 15.32 & 12.40 & 3.22 & 3.32 & 1.77 & 14.5 & 0.19 \\
\hline \multicolumn{10}{|l|}{ Stage 3} \\
\hline $\mathrm{T} 1$ & 83.69 & 19.05 & 14.46 & 11.22 & 3.21 & 2.48 & 3.25 & 9.8 & 0.52 \\
\hline $\mathrm{T} 2$ & 124.17 & 23.11 & 15.05 & 11.88 & 3.16 & 2.73 & 2.08 & 17.8 & 0.15 \\
\hline T3 & 130.30 & 28.40 & 18.21 & 15.95 & 2.26 & 5.25 & 1.79 & 12.7 & 0.14 \\
\hline $\mathrm{T} 4$ & 127.71 & 27.36 & 17.27 & 15.33 & 1.93 & 3.29 & 2.25 & 11.6 & 0.42 \\
\hline T5 & 125.11 & 25.62 & 15.99 & 12.84 & 3.16 & 3.01 & 2.54 & 15.9 & 0.14 \\
\hline T6 & 128.26 & 25.36 & 15.93 & 12.72 & 3.22 & 3.62 & 2.27 & 14.4 & 0.13 \\
\hline $\mathrm{T} 7$ & 173.49 & 24.75 & 15.62 & 11.94 & 3.32 & 2.95 & 2.04 & 13.2 & 0.27 \\
\hline T8 & 184.81 & 23.58 & 15.33 & 11.56 & 3.44 & 3.15 & 1.92 & 11.9 & 0.37 \\
\hline T9 & 157.99 & 26.56 & 16.48 & 13.22 & 2.73 & 3.12 & 1.80 & 13.4 & 0.24 \\
\hline T10 & 171.11 & 26.91 & 16.92 & 14.13 & 2.45 & 5.19 & 1.48 & 21.4 & 0.21 \\
\hline T11 & 153.14 & 24.97 & 15.86 & 12.05 & 3.45 & 3.76 & 1.60 & 15.4 & 0.19 \\
\hline L.S.D 0.05 & 4.71 & 0.64 & N.S & 0.25 & N.S & 0.29 & N.S & 0.64 & 0.05 \\
\hline
\end{tabular}

1 (mg carotene/100 g F.W.), 2 (mg tannic acid/100 ml fruit juice), 3 (mg ascorbic acid/100 $\mathrm{ml}$ fruit juice), 4 ( $\mathrm{mg}$ malic acid/100 $\mathrm{ml}$ fruit juice). 
However, a significant high interaction effect on fruit retention before June drop and at harvest date were obtained in the second season only by spraying $\mathrm{GA}_{4}$ at pea + marble stages. Similar results were reported by El-Sabagh and Ahmed (2004) as they sprayed "Anna" apple trees with $\mathrm{GA}_{3}$ at petal fall stage.

\section{Fruit physico-chemical characteristics}

As for fruit physical characters (Tables 6 and 7) a significant interaction effect was obtained in both seasons.

Spraying $\mathrm{GA}_{4}$ at pea + marble stages gave the highest value of fruit weight. Similarly, El-Seginy et al. (2003) reported an increase in fruit weight by spraying "Anna" apple trees with $\mathrm{GA}_{3}$ after fruit set ( $2 \mathrm{~cm}$ fruit diameter) and after one month of fruit set. Moreover, Goldwin (1978) indicated that spraying Coxs orange pippen apple trees twice; at petal fall and one week before June drop with a mixture of gibberellins increased fruit size. However. In addition, spraying phosphoric acid at pea, marble and pea + marble stages resulted in highest value of TSS content in comparison with all other substances in the second season only (Table 7). Moreover, foliar sprays of phosphoric acid at pea + marble stages recorded the highest value of total sugars content in the first season only and, of reducing sugars in both seasons. These results are in line with those obtained by Eliwa et al. (2003) working on persimmon trees. In the second season spraying (Ascorbic + Citric acids) at pea + marble stages gave the highest value of non-reducing sugars. In addition, an interaction effect between sprayed chemicals and the fruit growing stage in accordance to fruit skin carotenoides content was recorded. Foliar sprays of phosphoric acid at pea + marble in both seasons and activated dry yeast at pea + marble stages in the second season recorded the highest value of carotenoides content without significant differences between them. However, no interaction effect on fruit tannins content was obtained in both seasons (Tables 6 and 7). Moreover, spraying activated dry yeast at pea + marble stages recorded the highest value of vitamin "C" content in both seasons. Similarly, Singh et al. (1994) reported that spraying seedless" grape vines with $\mathrm{GA}_{3}$ at berry set and two weeks later significantly increased vitamin "C" content. Moreover, foliar sprays of urea, phosphoric acid and (Ch. Fe + Ch. $\mathrm{Zn}+$ boric acid) at marble stage alone or pea + marble stages and foliar sprays of chelated calcium in the three spraying dates recorded the least values of fruit acidity without significant difference among them in the second season only.

These results are inconformity with those of Awad and Atawia (1995) working on pear trees, Fathi et al. (2002) working on peach and apple trees and Ahmed (2005) on peach trees.

\section{Conclusion}

It could be concluded that, spraying $\mathrm{GA}_{4}$, phosphoric acid and activated dry yeast at pea plus marble stages were the best and the most effective treatments in increasing fruit retention, yield and improving fruit quality and vegetative growth of the Costata persimmon trees.

\section{References}

Abd El-Wahab, A., M. Wafa, Samira Mohamed and A. M. Gihan. 2005. Effect of foliar application of some mineral elements on fruit set, yield, leaf and fruit mineral contents and storage ability of "Anna" apple fruits I- effect on fruit set, yield as well as leaf and fruit mineral contents. J. Agric. Sci. Mansoura Univ. 24(12):7547-7557.

Abd-Elmotty, Z. E. and M. I. F. Fawzy. 2005. Response of Zebda and Langra mango trees to some biofertilization treatments. J. Agric. Sci. Mansoura Univ. 30(6):3331-3341. 
Aboutalebi, A. and B. Beharoznam. 2006. Study on the effects of plant growth regulators on date fruit characteristics. International conference on date palm production and processing technology, book of abstracts.9- 11 May 2006 -Muscat, Oman.

Abd El-Ghany, N. A. 2005. Fruit drop. Agricultural Journal, 60 (3) : 21 22, Ministry of Agriculture - Egypt.

Ahmed, F. F., A. M. Akl, A. A. Gobara and A. E. M. Mansour. 1998. Yield and quality of "Anna" apple trees (Malus Domestica L.) in response to foliar application of Ascobin and Citrine fertilizers. Egypt. J. Hort. 25(2):203208.

Ahmed, F. F., O. H. Darwish, A. A. Gobara and A. H. Ali. 2002. Physiological studies on the effect of ascorbic and citric acids in combined with some micronutrients on "Flame Seedless" grape vines. Minia J. Agric. Res Dev. 22(1):105-114.

Ahmed, G. A. M. 2005. Effect of foliar application of some micronutrients on fruit quality changes and storage ability of "Desert Red" peach. Ph.D. Thesis, Fuc. Agric., Cairo Univ., Cairo, Egypt.

Alina, B. 1998. Effect of forchlorfenuron (CPPU) combined with NAA and carbaryl on fruit set and fruit characteristics in two apple cultivars. Acta Hort. 463:287-294.

AOAC. 1990. Official Methods of Analysis. 15th ed. Association of Official Analytical Chemists, Arlington, VA.

Attala, E. S., A. M. El-Seginy and G. I. Eliwa. 2000. Response of Le conte pear trees to foliar applications with active dry yeast. J. Agric. Sci. Mansoura Univ., 25(12):8005-8011.

Awad, S. M. and A. R. Atawia. 1995. Effect of foliar sprays with some micronutrients on "Le-Conte" pear trees. 2-tree fruiting and fruit quality. Annals, Agric. Sci., Ain Shams Univ., Cario, 40 (1): 369 - 377.

Blumenfeld, A. 1986. Improving productivity of "Triumph" persimmon. Alon. Hanotea, 40(7):539-544.

Cleland, C. F. 1995. Plant Hormones Phisiology, Biochemistry and Molecular Biology. P. J. Davies, (Ed). $2^{\text {nd }}$ Edition, Kluwer Academic Publishers, The Netherlands.

Dutta, P. and A. K. Banik. 2007. Effect of foliar feeding of nutrients and plant growth regulators on physicochemical quality of Sardar guava grown in West Bengal. Acta Hort. 335(6):407-411.

Eissa, F. M., M. A. Fathi and E. A. Kandil. 2007. Response of "Le - Conte" pear (Pyrus communis L.) trees to foliar application with some biostimulants. Minufiya J. Agric. Res. 32(4):11431154.

Eliwa, G. I., N. E. Ashour and M. M. Ali. 2003. Effect of girdling and foliar application with some sources of potassium and calcium on fruit drop, yield and fruit quality of persimmon trees. Egypt. J. Hort. 30(3-4):239 251.

Elizabeth, H. A. 1991. Evaluation of The Natural Drop of Flowers and Fruits From Persimmon Trees (Diospyros Kaki L.) Chillan, Chile, p. 129.

El-Sabagh, A. S. and E. A. M. Mostafa. 2003. Effect of Gibberellic acid $\left(\mathrm{GA}_{3}\right)$ treatments on vegetative growth, flowering density and fruiting of "Anna" apple cultivar. Alex. J. Agric. Res. 48 (2):75-86.

El-Sabagh, A. S. and H. S. Ahmed. 2004. Effects of Gibberellic acid $\left(\mathrm{GA}_{3}\right)$ and (Sitofex) on "Anna" apple crop load and fruit quality. Alex. J. Agric. Res. 49(1):71-79. 
El-Seginy, A. M., Malaka, S. M. Naiema, W. M. Abd El-Messeih and G. I. Eliwa. 2003. Effect of foliar spray of some micronutrients and Gibberellin on leaf mineral content, fruit set, yield and fruit quality of "Anna" apple trees. Alex. J. Agric. Res. 48(3):137-143.

El-Shaikh, A. A., B. M. Khalil and A.Y. Hamza. 1999. The effect of girdling and some growth regulators on fruit drop of persimmon. Egypt. J. Agric. Res. 77(4):1707 - 1724.

El-Shewy, A. A. 1999. Response of guava trees to some chemical substances spray. Ann. Agric. Sci. 37(3):16491661.

Fathi, M. A., B. A. Shahin and H. Mokhtar. 1999. Improving yield and fruit quality of apple and pear by spraying some chemical substances. Minufiya J. Agric. Res. 24(5):1765-1776.

Fathi, M. A., F. M. Eissa and M. M. Yehia. 2002. Improving growth, yield and fruit quality of "Desert Red" peach and "Anna" apple by using some biostimulants. Minia J. Agric. Res. Dev. 22(4): 519-534.

Gihan, A. M. 2005. Effect of foliar application of some micronutrients on fruit quality changes and storage ability of "Desert Red" peach. Ph.D. Thesis, Fuculty of Agriculture, Cairo University, Cairo, Egypt.

Goldwin, G. K. 1978. Improved fruit setting with plant growth harmones. Acta Hort. 80:115 - 122.

Goodwin, T. W. and E. I. Mercer. 1983. Introduction to Plant Biochemistry. $2^{\text {nd }}$ Edition, Pergamon Press, p. 592.

Haidry, G. A., Jalal-ud-Din and M. Munir. 1997. Effect of NAA on fruit drop yield and quality of mango, Mangifera indica cultivars Langra. Scientific Khyber. 10(1):13-20.
Hassan, A. S. A. 2002. Effect of some $\mathrm{GA}_{3}$, yeast, nitrogen and potassium foliar spray treatments on yield, fruit quality and leaf characteristics of "Thompson Seedless" grape vines. Zagazig. J. Agric. Res. 29(1):73-79.

Hassona, M. G. 1967. Fundamental of plant physiology. $3^{\text {rd }}$ Edition. Dar ElMaaref, Egypt, pp. 163 - 196.

He Wei Hua, Huang Xian Gan, Wang Rui Yun, Li Shan Hu, Huang Chun Xia and Y. W. Fang. 1998. Studies on the effect of application of calcium nitrate on apple trees. J. Fruit Sci. 15(1):20 - 25 .

Hossain, M. B. and K. S. Ryu. 2009. Effect of foliar applied phosphatic fertilizer on absorption pathways, yield and quality of sweet persimmon. Sci. Hort 122(4):626-632.

Iqbal, M, M. Q. Khan, Jalal-ud-Din, K. Rehman and M. Munir. 2009. Effect of foliar application of NAA on fruit drop, yield and physico-chemical characteristics of guava (Psidium guajava L.) Red flesh cultivar. J. Agric. Res. 47(3):259-269.

Ismaeil, F. H. M., M. T. Wahdan and A. F. El-Sheikh. 2003. Response of "Thompson Seedless" and "Romi Red" grape cultivars to foliar sprays with yeast extract and $\mathrm{GA}_{3} \mathrm{~J}$. Agric. Sci. Mansoura Univ. 28(8):63216334.

Kabeel, H. 1999. Effect of some growth regulators on fruit set, yield and fruit quality of "Costata" persimmon trees. Minufiya J. Agric. Res. 24(5):1727-1739.

Kabeel, H. and S. M. M. El-Saadany. 2004. Effectiveness of mineral fertilizers application and boron sprays on some fruiting parameters, fruit quality and leaf nutrient content of "Le-Conte" pear trees. Egypt. J. Appl. Sci. 19(9B):658-679. 
Malik, C. P. and M. B. Singh. 1980. Plant Enzymology and Histoenzymology. A. Text Manual, Kalyani publishers, New Delhi, India.

Mansour, A. E. M. 1998. Response of "Anna" apples to some biofertilizers. Egypt. J. Hort. 25(2):241-251.

Maurya, A. N. and J. N. Singh. 1981. Effect of three growth regulators on fruit retention and quality of mango (Mangifera indica L.) cv. Langra. J. Agri. India 16(3):53-56.

Moore, T. C. 1979. Biochemistry and Physiology of Plant Hormones. Springer - Verlage, New York, U. S. A.

Nelson, N. 1944. Determination of reduced sugars. J. Biol. Chem. 153:375.

Nomier, S. A. 2000. Effect of some vitamins and active dry yeast treatments on vegetative growth, yield and fruit quality of "Thompson seedless" grape vines. Zagazig J. Agric. Res. 27(5):1267-1286.

Ranjan, R., S. S. Purohit and V. Prasad. 2003. Plant Hormones: Action and Application. Agrobios, India, pp. 183-189.

Rizzi, E. and A. Abruzzese. 1990. Effect of calcium treatment on some biochemical indexes during the developing of apple fruit. Agric. Mediter. 118(4):311 - 317.

Schafer, G., O. C. Koller and I. A. Sartori. 1999. Fruit retention of Monte Parnaso Navel oranges in relation to application of 2,4-D, gibberellic acid and shoot ringing. Ciencia Rural 29(4):639-644.

Shoeib, M. M. and A. El_sayed. 2003. Response of "Thompson Seedless" grape vines to the spray of some nutrients and citric acid. Minia J. Agric. Res. Dev. 23(4):681-698.

Singh, S., I. S. Singh and D. N. Singh. 1994. Effect of $\mathrm{GA}_{3}$ on ripening and quality of grape (Vitis vinifera L.). Orissa J. Hort. 22(1-2):66-70.

Steel, R. and J. Torrie. 1980. Principles and Procedures of Statistics: A Biometrical Approach. $2^{\text {nd }}$ Edition, McGraw-Hill Book Company. p. 580 .

Wally, A. S. M. 2003. The persimmon. Extension Bulletin No. 856/2003, Ministry of Agriculture, Egypt (Arabic).

Wally, A. S. M., A. M. El-Seginy and M. S. Naeima. 2004. Effect of $\mathrm{GA}_{3}$, Promalin and Kristalon on "Anna" apple seedling growth. J. Agric. Sci. Mansoura Univ. 29(2):749-759.

Wally, A.S.M., H. Mokhtar and E.M. ElFakahany. 1999. Effect of Biozyme and Gibberellic acid on fruit set, yield and fruit characters of "Costata" persimmon. Egypt. J. Agric. Res. 77(2):805-815.

Wasfy, E. H. 1995. Growth Regulators and Flowering. Academic Bookshop, Egypt, pp. 560 - 580 (In Arabic).

Westwood, M. N. 1978. Temprate-Zone Pomology. Freeman, San-Francisco, U.S.A.

Wignarajah, K. 1995. Mineral Nutrition of Plants. In: M. Pessarakli (Ed.) pp. 201-206. Hand Book of Plant and Crop Physiology, Marcel Dekker, Inc.

Youn, C. K, S. K. Kim, S. C. Lim, Y. H. Kim, Y. Yoon and T. S. Kim .2004. Effect of promalin and salicylic acid application on tree growth and fruit quality of "Tsugaru" apples. Acta Hort. 653:151-154. 